\title{
Jarosław Bedyniak
}

\section{Poezja i zmysły. Antyczny topos wody i wina jako teoria iudicium litterarium w twórczości Jana Kochanowskiego}

\begin{abstract}
Bedyniak Jarosław, Poezja i zmysły. Antyczny topos wody i wina jako teoria iudicium litterarium $w$ twórczości Jana Kochanowskiego [Poetry and the senses. The ancient topos of water and wine as a theory of literary taste in the works of Jan Kochanowski]. „Przestrzenie Teorii" 27. Poznań 2017, Adam Mickiewicz University Press, pp. 317-342. ISSN 1644-6763. DOI 10.14746/pt.2017.27.20.
\end{abstract}

The text refers to the ancient topos of the debate on drinking water and wine, which is present in Jan Kochanowski's poetry. The ancient idea of bacchanalian drink and water from the holy spring were seen as the root of the act of creation. Ever since this motif took its final shape in the works of the Anthology poets, it has been used by artists as a pretext for self-referential reflections, as well as for technical musings on sources of inspiration. The classical thread takes on special significance in Kochanowski's work, because the poet uses it to articulate his own concept of poetic inspiration (enthusiasm), and also because he formulates aesthetic judgment (iudicium) on the criteria for evaluating literature.

Wyobraźnia poetycka stanowi rację dostateczną literackiego bytu unaoczniających przedstawień procesu twórczego. Na kartach poezji, zwłaszcza dawnej, niejednokrotnie pojawiają się sugestywne sceny warsztatowych wtajemniczeń1. Autor spotyka - na jawie lub we śnie - bóstwa, prawodawców gatunków, a także przyszłe postaci swojego utworu². Niekiedy otrzymuje też od nich stosowne atrybuty (skeptron, lirę). Bywa,

${ }^{1}$ Problematyce metapoetyckiej w poezji starożytnej i staropolskiej poświęcone zostały w całości lub części następujące pozycje: E. Sarnowska-Temeriusz, Renesansowe pojęcie poezji $w$ Polsce, [w:] Problemy literatury staropolskiej. Seria druga, red. J. Pelc, Wrocław 1973, s. 459-492; taż, Droga na Parnas. Problemy staropolskiej wiedzy o poezji, Wrocław 1974 (szczególnie rozdz.: Poeci staropolscy o poezji, s. 154-198); T. Michałowska, Poetyka i poezja. Studia $i$ szkice staropolskie, Warszawa 1982, rozdz.: Poetyka i poezja (Problemy interpretacji poezji staropolskiej), s. 140-178; J. Kotarska, „Kastalskie zdroje Muz”. Z dziejów topiki Apollińskiej, [w:] tejże, Theatrum mundi. Ze studiów nad poezja staropolska, Gdańsk 1998, s. 179-196; C. Maleszyński, Pszczoła - „archipoeta” (teoria mimesis $w$ dawnej metaforze), [w:] Mimesis $w$ literaturze, kulturze i sztuce, red. Z. Mitosek, Warszawa 1992, s. 273-306; J. Brzozowski, Muzy w poezji polskiej. Dzieje toposu do przetomu romantycznego, Wrocław 1986; T. Mojsik, Antropologia metapoetyki. Muzy w kulturze greckiej od Homera do końca V w. p.n.e, Warszawa 2011.

2 Zob. T. Mojsik, dz. cyt., s. 222-255. Na temat różnych funkcji Muz, w tym przypisywanej im roli dawczyń natchnienia, zob. J. Brzozowski, dz. cyt., zwłaszcza s. 14, 85, $238-239$. 
że uzyskanie pożądanej sprawności poprzedzają wykonywane przez poetę gesty: zbieranie kwiatów z łąk Helikonu, maczanie pióra w Hipokrene czy wspinanie się na szczyt Parnasu. Pośród symbolicznych przedstawień pisarskiej inicjacji ważne miejsce przypadło zmysłowej figurze picia wina i wody z parnaskiego strumienia ${ }^{3}$.

Obraz autora wybierającego między napojem ze zdroju Muz a trunkiem Bachusa pojawia się w antycznej, a także nowożytnej poezji nowołacińskiej. Szczególnie chętnie odwołuje się do niego Jan Kochanowski, którego bez wątpienia można nazwać piewca wina. Czarnoleski poeta niejednokrotnie przekonuje, że trzeźwy nie ma mocy twórczej. W pieśni dwudziestej pisze: „Znał kto kiedy poetę trzeźwiego?/ Nie uczyni taki nic dobrego" $(1,20$, w. 13-16) . We fraszce zatytułowanej $O$ swych rymiech z kolei deklaruje, iż między jego twórczością a tym, jak żyje, istnieje określona zależność: „Ja inaczej nie piszę, jeno jako żyję,/ Pijane moje rymy, bo i sam rad pije" $(3,17$, w. 1-2)

Te oraz podobne wypowiedzi skłaniają, by koncentrując się wokół topiki sympotycznej w polskiej i łacińskiej poezji mistrza z Czarnolasu, podjacć refleksję nad zagadnieniem poetyckiej inspiracji. Symboliczne znaki i zwerbalizowane $\mathrm{w}$ twórczości poety sądy na temat natchnienia zachęcają do zestawienia ich z ideami ówczesnej estetyki. Przyjrzenie się wymienionym elementom, być może, pozwoli lepiej zrozumieć pojmowanie przez autora Fraszek procesu tworzenia, a przywoływane przez niego w ekskursach wypowiedzi na temat genezy poezji umożliwią poznanie figuralnych sposobów artykułowania kryteriów i ocen jakości literatury.

\section{U źródeł}

Rozważania nad koncepcją natchnienia poetyckiego, wyraźnie nawiązującą u Kochanowskiego do wyobrażeń sympotycznych, wypada poprzedzić niezbędnym dla dalszych dociekań przedstawieniem klasycznego zaplecza. Poszukiwania artystycznych źródeł, w których przypisuje się wodzie lub winu zdolność inspiracji poetyckiej, prowadzą do samych korzeni literatury europejskiej, a więc do starożytnej Grecji. Pierwszym

3 Szczegółowe przedstawienie toposu wody i wina w literaturze antycznej przynosi praca N.B. Crowthera: Water and Wine as Symbols of Inspiration, „Mnemosyne” 1979, 32, nr 1/2, s. 1-11. Zob. też P.E. Knox, Wine, Water, and Callimachean Polemics, „Harvard Studies in Classical Philology" 1985, 89, s. 107-119.

${ }^{4}$ Cyt. wg wydania: J. Kochanowski, Pieśni, [w:] tegoż, Dzieła polskie, wyd. 2, zupełne, wstępem i przypisami opatrzył J. Krzyżanowski, Warszawa 1953, t. 1, s. 261-344.

${ }^{5}$ Cyt. wg wydania: J. Kochanowski, Fraszki, oprac. J. Pelc, Wrocław 2004. 
autorem piszącym o wodzie ze świętych strumieni był Hezjod (Teogonia $1,1-6)$ :

\author{
Od helikońskich Muz rozpocznijmy nasze śpiewanie - \\ one to Helikonu szczyt dzierżą wielki i boski \\ i dokoła ciemnego źródła miękkimi stopami \\ tańczą i wokół ołtarza przepotężnego Kronosa; \\ i delikatne ciała obmywszy wodą z Permessu \\ albo z Końskiej Krynicy, albo z boskiego Olmeju ${ }^{6}$.
}

U autora Teogonii brak jeszcze motywu picia ze źródła Hipokrene „Końskiej Krynicy”. Wymienione tu trzy święte rzeki (Hipokrene, Permessus i Olmeus) pełnią jedynie funkcję łaźni Muz. Boginie obdarowują poetę gałązką wawrzynu (w. 30-31) i nauczają pięknego śpiewu, gdy ten wypasa owce u stóp Helikonu (w. 22-23). Mimo to w późniejszej literaturze występuje przekaz o rzekomym czerpaniu przez Hezjoda wody z Pegazowego zdroju. Pojawia się w epoce aleksandryjskiej, a wiąże się z twórczością poetów tak zwanej Antologii Palatyńskiej.

Żyjący pod koniec IV wieku p. Ch. Asklepiades pisze, że autor Pracy $i$ dni nie tylko otrzymał gałązke z drzewa laurowego od Muz, ale i skosztował wody z „Końskiego Źródła” (Anthologia Palatina 9, 64). O tym, iż to parnaski zdrój dał natchnienie Hezjodowi, wspomina także Antypater z Tessaloniki ( $A P$ 11, 24), który stwierdza ponadto, że sam ceni bardziej wychylenie kubka wina niż skosztowanie wody ze źródła Muz. W innym utworze z kolei mówi, iż stawia wyżej picie wina na cześć Homera i Archilocha niż wody z Hipokrene $(A P 11,20)$. Wraz z poezją twórców doby aleksandryjskiej zapoczątkowana została „debata” nad piciem bachusowego trunku i wody ze świętego strumienia.

Niezależnie od wspomnianej poetyckiej dyskusji, zainicjowanej w epigramatyce, inspirującą wartość winu (nie przeciwstawiając go jednak wodzie) przyznają już greccy poeci epoki archaicznej. „Umiem władcy Dionizosa/ piękne pieśni - dytyramby/ intonować, kiedy wino/ niczym piorun mnie porazi” - pisze Achirloch7, zaś Anakreont wyznaje: „tylko trochę ułamałem sobie placka,/ za to wina dzban wypiłem;/ teraz lekko trącam w struny/ wdzięcznej liry i piosenkę/ śpiewam miłej mej ślicznotce"8. Myśl, że picie, szczególnie umiarkowane, pomaga korzystać w pełni

${ }^{6}$ Cyt. wg wydania: Hezjod, Narodziny bogów (Theogonia), [w:] tegoż, Narodziny bogów (Theogonia). Prace i dni. Tarcza, przełożył, wstępem i przypisami opatrzył J. Łanowski, Warszawa 1999.

7 Archirloch 120, [w:] Liryka starożytnej Grecji, oprac. J. Danielewicz, wyd. 3, Wrocław 1987, s. 14.

8 Anakreont 28 (373), [w:] tamże, s. 100. 
z rozmów prowadzonych podczas uczty i deklamować w jej trakcie poezję, gości także u wielu późniejszych twórców greckich, uprawiających różne gatunkach literatury. Grecki komediopisarz z III wieku, Aleksis, stwierdza, że wino „rozmów miłośnikami czyni wszystkich ludzi, którzy piją go dużo”. „Pijmy więc! Bo przy winie znajdę nowe słowa/ wyszukane, co $\mathrm{w}$ sobie słodycz mają miodu" - powiada $\mathrm{z}$ kolei w jednym $\mathrm{z}$ epigramatów Hedylos ${ }^{10}$. Motyw wina, wprowadzającego nastrój pogodnej zabawy i pomagającego w prowadzeniu towarzyskich rozmów, pojawia się zwłaszcza w elegiach biesiadnych (Kritias 6, 16; Euenos 8, 27)11.

Słynnych starożytnych poetów „wino-” oraz „wodopijców” wymienia Atenajos. Pisze w Uczcie mędrców: „poeta liryczny Alkajos i komediopisarz Arystofanes pisali swoje utwory po pijanemu, a wielu innych zabłysnęło w walce dzięki temu, że sobie popili"12. O Ajschylosie zaś powiada, że tworzył tragedie w stanie upojenia alkoholowego ${ }^{13}$. Picie wina dla inspiracji poetyckiej przypisuje twórca $\mathrm{z}$ Neukratis ponadto Teognisowi $\left(10,428\right.$ c), Ionowi $(10,436 \mathrm{f})^{14}$, a nawet Hezjodowi $(10,428 \mathrm{c})$. W tymże samym dziele autor wskazuje również słynnych zwolenników poezji z wody wziętej. Mieli zaliczać się do nich Ofelion i Eubulos, którzy głosili, że woda czyni pijących ją pełnymi pomysłów, w przeciwieństwie do wina (ono „chmurą rozum [...] zaciemnia”; 2,43 f).

Tradycję poetyckiej debaty nad znaczeniem w procesie kreacyjnym wody i wina „kontynuował” w literaturze rzymskiej Horacy. W Listach $(1,19)$ podjął krytykę twórczości poetów pijących wodę (w. 1-11):

Prisco si credis, Maecenas docte, Cratino,
nulla placere diu nec vivere carmina possunt,
quae scribuntur aque potoribus. Ut male sanos
adscripsit Liber Satyris Faunisque poetas,

${ }_{9}$ Cyt. wg wydania: Atenajos, Uczta mędrców, przeł., wstępem i przypisami opatrzyli K. Bartol (księgi I-II, VI-VII, XI-XII, XIV, XV 665 a-686 c) i J. Danielewicz (księgi III-V, VIII-X, XIII, XV 686 d-702 c), Poznań 2010; 2,39b. Polski tłumacz występujące w oryginale filologos oddał jako „rozmów miłośnikami”. Por. komentarz na temat tego miejsca oryginału w pracy Mariana Wesołego: „Pozostający pod wpływem filozofii komediopisarz Aleksis (ok. 372 - ok. 272) stwierdzał, że »wino czyni filologami wszystkich tych, którzy więcej go piją« [...]. Określenie philologos, podobnie jak u Platona (Resp. 582 e; Leg 641 e; Phdr 236 e), oznacza tu człowieka wykształconego, miłośnika wywodów i mądrości" (Ion piewca wina i madrości, [w:] Litteris vivere. Księga pamiatkowa ofiarowana profesorowi Andrzejowi Wójcikowi, red. I. Lewandowski, K. Liman, Poznań 1996, s. 54).

10 Atenajos, dz. cyt., 11, 473 a.

11 Zob. też: Theognidea 763 i 1047 oraz Platon (Convivium IV c-e).

12 Atenajos, dz. cyt., 10, 429 a oraz 10, 430 a.

13 Tamże, 1,22 a; 10, 428f-429 a oraz Plutarch (Quaestiones convivales $622 \mathrm{e}$ ),

14 Tamże, 10, 436 f („Baton z Synopy w dziele $O$ poecie Ionie mówi, że Ion lubił pić i był bardzo kochliwy"). 
vina fere dulces oluerunt mane Camenae. laudibus arguitur vivni vinosus Homerus; prosiluit dicenda. 'forum putealque Libonis mandabo siccis, adimam cantare severis': nocturno certare mero, putere diurno ${ }^{15}$.

W wypowiedzi stylizowanej na pretorski dekret podmiot „atakuje” twórców trzeźwych, zajmujących się pisaniem poezji (quae scribuntur aque potoribus), przypominając, że już tak szacowni autorzy jak Homer i Enniusz pijali wino. Wenuzyjski poeta mówi o prawdziwych artystach i poślednich naśladowcach. Tym, co cechuje poezję $\mathrm{z}$ wina wziętą, jest oryginalność (w. 19-20)16. Przestawiony w utworze spór między „wino-" i „wodopijcami”, zdaniem badaczy, stanowi odbicie dyskusji, jaka toczyła się w antycznym Rzymie wśród zwolenników twórczości uczonej (woda) i orędowników poezji z życia wziętej (wino) ${ }^{17}$. Przekonanie starożytnych o inspirującej wartości bachusowego trunku miało przetrwać w późniejszej poezji ${ }^{18}$ (w tym również w twórczości Kochanowskiego), choć nie wszyscy poeci nowożytni byli w tej kwestii jednomyślni.

Pierwsi autorzy staropolscy, podejmując antyczny topos, zdecydowanie opowiadają się za poezją z Hipokrene wziętą. Jan Dantyszek w utwo-

15 „Rzekł prawdę stary Kratyn, uczony Meceno:/ „Ta długo nie pociągnie, źle słychać z Kameną,/ Co pije wodę”. Odkąd wieszczowie szaleni/ Do Satyrów przez Bakcha i Fałnów wliczeni,/ Muzę czuć rano winem, a pochwały wina/ I Homera zdradzają, że był pijaczyna./ $\mathrm{Ba}$, i nasz ojciec Enniusz także nie inaczej,/ Tylko wina golnąwszy bój śpiewał junaczy./ „Forum dla trzeźwej tłuszczy, co się o grosz bije,/ Ale wam do poezji wara, wodopije!” (w. 1-10; przekład J. Czubek). Wszystkie cyt. oryginalne wg wydania: Quintus Horatius Flaccus, Opera, editio minor tertia, iterum recognovit F. Vollmer, Lipsiae 1927; przekłady cyt. wg wydania: Horacy, Wybór poezji, oprac. J. Krókowski, Wrocław 2007.

16 Zob. na ten temat N.B. Crowther, dz. cyt., s. 9.

17 A. Wójcik, Problematyka literacka w twórczości Horacego, Poznań 1978, s. 15-16. Zob. też na temat debaty nad piciem wody i wina w elegii rzymskiej: Ch.P. Frost, Propertius 3.3.45: Don't Go Near the Water, Baltimore, ML, 1991, 112, nr 2, s. 251-259.

18 Warto dodać, iż topos wina i wody w analogicznym ujęciu „debaty”, tyle że przybierającej charakter „poswarku”, odnajdujemy również w literaturze średniowiecznej (zob. J.H. Hanford, De Medieval Debate between Wine and Water, „PMLA” 1913, 28, nr 3, s. 315-367; M. Lenart, Spór duszy z ciatem i inne wierszowane spory $w$ literaturze staropolskiej na tle tradycji średniowiecznej, Opole 2002, s. 187-191), przy czym należy tu mówić raczej o paralelach, nie zaś o bezpośrednich kontynuacjach sympotycznej tradycji starożytnej. Temat alegorycznego sporu obu napojów podejmą później polscy poeci siedemnastowieczni. Warto wspomnieć tu choćby łaciński i polski Sen dziwny, w którym wino $i$ woda o godnościach swych rozprawuja Jana Libickiego (Somnium prodigiosum de Vino et Aqua mutuo inter se pro dignitas Apice litigantibus. Sen dziwny, w którym wino $i$ woda o godnościach swych rozprawuja przez I. L. S. I. K. M. napisany, Kraków 1647) czy też Poswarek Wina $z$ Woda, przypisywany Adrianowi Tyszce (b. r. i m. w. [dwie edycje; wg Estreichera: 1620-1650]). 
rze Ad iuventutem ${ }^{19}$ przyznaje, że jego wiersz może okazać się niezbyt gładki (non rite politum), za co winą obarcza dwóch bogów: z tyrsem (thyrsigero) i z łukiem (arcifero). Chodzi oczywiście o Apollina - towarzysza i przewodnika Muz, oraz Bachusa - boga wina. Twórca ubolewa, że nie ukochał Muz (Pierides) i pił więcej wina (Bromii) niż świętej wody (non saepe sacra fontis aqua). Gdyby czynił inaczej, jego poezja byłaby dopracowana, a skronie wieńczyłby laur - symbol uznania i znak osiągnięcia wysokiego kunsztu poetyckiego. Woda, również ta pochodząca ze świętego strumienia, odgrywa niezwykle ważną rolę w poetyckiej symbolice Klemensa Janicjusza ${ }^{20}$. W skierowanej do padewskiego mistrza Łazarza Bonamiko elegii 6 z Księgi żalów twórca z Januszkowa oświadcza, iż obmywszy stopy, wstąpił na górę Apollina, gdzie pił wodę z bezcennego zdroju, należącego do Muz i ich opiekuna (w. 11-22)21. Obaj polsko-łacińscy autorzy przypisują inicjującą moc wodzie ze świętego źródła i stawiają ją wyżej od wina ${ }^{22}$.

\section{Zmysłowy czar poezji}

Inną drogą inspiracji twórczej podąża Kochanowski. Cechą wspólną wszystkich metapoetyckich wypowiedzi czarnoleskiego twórcy, w których pojawia się debata nad piciem hipokreneńskiej wody i bachusowego napoju, jest uznanie wyższości tego ostatniego. Uwzględniając funkcję, jaką u autora Pieśni spełnia antyczny motyw, a także biorąc pod uwage roz-

${ }_{19}$ „Pierides si sic adamassem forte sorores,/ Cinxissent nostrum laurea serta caput./ Pocula si pluris Bromii non saepe fuissent/ Hippocrenaei quam sacra fontis aqua,/ Iam mea doctiloquis prodirent carmina plantis,/ In numeris esset dexter Apollo meis" (w. 4550). „Gdybym tak samo Muzy ukochał siostrzane,/ Już by laur opasywał moją głowę./ Gdybym błogosławionej wody Hipokreńskiej/ Więcej spełnił w swym życiu niźli wina,/ Już biegłyby me pieśni uczonymi tropy,/ Już by Apollo stroił moje miary". Fragment łaciński wiersza i polski przekład cyt. wg wydania: J. Dantyszek, Pieśni, wybór i tłum. A. Kamieńska, wstęp Z. Nowak, wyd. 2, zmienione, Olsztyn 1985, s. 42-43.

20 O motywach akwatycznych, składających się na „poetycką antroposferę” u Janicjusza zob. D.C. Maleszyński, Wody u Janicjusza, „Polonistyka” 2012, 76, nr 2 (494), s. 6-9.

${ }^{21}$ K. Janicki, Carmina. Dzieła wszystkie, wydał i wstępem (I) poprzedził J. Krókowski, przełożył E. Jędrkiewicz, wstęp (II), komentarz, similia, appendices, słownik imion własnych i indeks oprac. J. Mosdorf, Wrocław 1966, s. 42.

${ }^{22}$ Odrębnym zagadnieniem jest chrystianizacja toposu, jakiej dokonał m.in. Dantyszek we wstępie do Hymnów kościelnych. Por. tenże, Do czytelnika: „Ni na cześć dziewięciu Muz,/ Dla Feba też nie piszę owych hymnów;/ Tu nie płynie bystry zdrój,/ Co trysł spod kopyt skrzydlatego konia/ Piętna Chrystusowych ran,/ Co krwawią się, książeczka ta zawiera [...]" (przekład J.M. Harhala). Cyt. wg wydania: Najstarsza poezja polsko-łacińska (do połowy XVI wieku), oprac. M. Plezia, Wrocław 2005, s. 131. 
ległość towarzyszących mu autotematycznych konstatacji, należy wyróżnić kilka jego wariantów.

Do pierwszej grupy można zaliczyć teksty, w których występuje sympotyczna debata, lecz towarzyszy jej niewielki zasób refleksji na temat natchnienia poetyckiego. W fragmencie elegii 2,2 , stanowiącym parafrazę, dość wierną, kilku wersów z pieśni konwiwialnej Katullusa, poeta kieruje apostrofe do chłopca-podczaszego: „Huc calices crebros infer, puer, huc age lymphas!/ Sed lymphas aliis porrige, vina mihi!" (w. 9-10)23. Podobnie jak u twórcy z Werony ${ }^{24}$, tak w wierszu Kochanowskiego podmiot wyraża prośbę, by sługa przyniósł kielichy z winem, nie zaś z wodą; tę przeznacza bowiem dla pozostałych biesiadników. Identyczna sympotyczna sytuacja występuje również w elegii 2,7 , przy czym tutaj już sam podmiot-poeta rezerwuje dla siebie wino, dla pozostałych - wodę (w. 1-4):

Spare, puer, violas et stactae profer odores,

Et remove lymphas, et mihi funde merum!

Non ego aquam, si sim malus asque poeta futurus,

Sit licet Aonio fonte petita, bibam ${ }^{25}$.

23 „Chłopcze! gęste puchary tu dawaj, tam wody,/ Wody dla innych, dla mnie sok winnej jagody". Wszystkie cytaty z łacińskiej poezji Kochanowskiego wg wydania: J. Kochanowski, Carmina Latina. Poezja tacińska. Pars prior Imago phototypica - transcriptio. Część I. Fototypia-transkrypcja, edidit, praefstione et apparatu critico instruxit/ wyd. i wstępem poprzedziła Z. Głombiowska, Gdańsk 2008; przekłady - wg wydania: J. Kochanowski, Z łacińska śpiewa Stowian Muza. Elegie foricenia, liryki w przekładzie Leopolda Staffa, wstępem poprzedził Z. Kubiak, Warszawa 1982.

24 Por. „Minister vetuli puer Falerni/ Inger mi calices amoriores/ [...]. At vos quo lubet hinc abite, lymphae/ Vini pernicies, et ad severos/ Migrate: hic merus est Thyonianus" (cyt. wg wyd.: Q. Catullus, Carmina, recensuit E. T. Müeller, Lipsiae 1919, s. 14). Przekład brzmi: „Chłopcze, co stare falernum podajesz,/ win bardziej cierpkich do kielicha nalej,/ [...] Precz mi z tą woda - to wina zakała! Niech tam ją piją, gdzie surowe miny!/ My zostaniemy tu z Tyony synem" (cyt. wg wyd.: Katullus, Poezje, przełożyła A. Świderkówna, opracował J. Krókowski, Wrocław 1956, s. 25). Por. też: Anacreont 356, 1-2: ớ

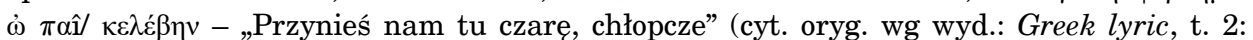
Anacreon, anacreontea choral liryc from Olympus to Alcman, with an English transl. by D.A. Campbell, Cambridge, Mass. - London 1988, s. 54; przekład - wg wydania: Liryka starożytnej Grecji, s. 97. Zob. też Anakreont (396). Obraz podczaszych napełniających kielichy występuje w wielu utworach literatury starożytnej; por. np. Homer (Odyssea 10, 356-357); Safona $(2,15-16)$.

25 „Syp fiołki, dobądź wonnych olejków, chłopczyno,/ Precz z wodą, do pucharów lej mi tylko wino./ Choćbym miał być poetą lichym, po próżnicy/ Lałbyś mi wodę, nawet z aońskiej krynicy". Konwencjonalna i znana z literatury starożytnej apostrofa do chłopca-podczaszego, będacca apelem o wino, mogła być połączona z prośbą o wieńce z kwiatów i olejki do nacierania. Na temat namaszczania wonnościami ( $\mu$ v́pov) związanego z ucztą zob.: Ksenofanes (1,3); Homer (Ilias 6,483; 14,171-172; Odyssea 18,192-194); Archiloch (48, 5-6; 205); Alkajos (362, 3); Anakreont (363, 3); Semonides (7, 64; 16, 1); Ksenofanes (3). 
Literat powiada, że choćby miał na zawsze pozostać słabym twórcą, a serwowana woda zaczerpnięta była $\mathrm{z}$ aońskiego źródła, to woli pić wino. Owo źródło, o którym mowa, to Hipokrene, nazwane tak od mieszczącej się w pobliżu Helikonu równiny Aonu - części Beocji.

Do drugiej grupy należą utwory, w których kwestia: czy pić wino, czy wodę (pochodzącą - w tym przypadku - zawsze ze świętego zdroju), nie tylko została rozstrzygnięta, jak miało to miejsce poprzednio, na korzyść bachusowego trunku, ale i - co szczególnie interesujące - Kochanowski mówi tu więcej o literackich powodach podjęcia takiej decyzji. Wypowiedzi te łączą - nierzadko w sposób humorystyczny - koncepcję furor divinus $\mathrm{z}$ naturalistyczną teorią inicjacji poetyckiej, która bywa, o czym świadczą kreowane obrazy, jednym z komponentów procesu twórczego.

Pogląd, iż Hipokrene, wbrew temu, co głosili starożytni, wcale nie jest źródłem inspiracji poetów, a Muzy nie są orędowniczkami pijących wodę, Kochanowski wyraził w foricoenium 78, skierowanym Ad Petrum:

\footnotetext{
Nugae profectò sunt merae, Meraeq[ue], Petre, fabulae, Quae de volucris fonte equi

Vates vetusti garriunt.

Vinum est póétas quod facit

Et blanda dictat carmina:

Aquam bibentibus nihil

Insigne Musa subjicit.

Horum locupes, ô Petre,

Testis vel ipse sim tibi,

Qui sobrius possum nihil,

Nisi immerente dentibus

Cunctator ungueum rodere.

Sed paulo ubi plus adbibi,

Animusq[ue] concaluit mero,

Statim moveri sentio

Praecordiis in intimis

Innumera versuum agmina

Erumpere gestientia.

Quibus data est postquam via,

Ruunt gregatim more apum,

Hiberna quas post frigora

Amicta prata floribus,

Et veris invitat tepor ${ }^{26}$.
}

${ }^{26}$ Do Piotra

„Fraszki to wierutne, Piotrze,/ Lepszych znaleźć się nie zdarzy,/ Co o Pegazowym źródle/ Bają nam poeci starzy./ Toć poetów wino stwarza/ I winem tylko pieśń żyje./ Muza nic 
Poeta z Czarnolasu, kontestując prawdziwość starożytnych przekazów o „Końskiej Krynicy”, używa dwóch określeń, które oznaczają formy gatunkowe: nuga i fabula. Pierwszy jest odpowiednikiem żartu, drugi zaś bajki. Oba terminy mają zapewne wskazywać na niezbyt poważne i mało wiarygodne przekazy, w jakich dawni poeci przekonywali o inspirującej właściwości wody ze świętego źródła. Według podmiotu tylko wino jest prawdziwym źródłem weny. Ono stwarza (facit) twórców i dyktuje (dictat) im czarujące wiersze (blanda carmina). Temu, kto pija wodę, Muza nie podsuwa zgrabnej materii, mogącej posłużyć za podstawę wiersza. Bo przecież kiedy autor jest trzeźwy, występują u niego dość kłopotliwe objawy niemocy twórczej (sobrius possum nihil): namyśla się długo i obgryza paznokcie. Dopiero trunek, który rozgrzewa jego umysł (animus concaluit), przynosi natchnienie - sprawia, że z piersi wydobywają się pieśni.

Kwestia o rozgrzewaniu umysłu stanowi nawiązanie do Arystotelesowskiej koncepcji humoralnej27, wedle której zarówno wino, jak i melancholia (jeden z czterech temperamentów ludzkich) to czynniki najbardziej sprzyjające wszelkiej aktywności intelektualnej. Działanie w organizmie człowieka czarnej żółci - substancji utożsamianej niekiedy z krwią żylną, mającą właściwość, jakiej nie posiadają pozostałe humory, tj. podstawę mocy twórczej28 - porównywał Stagiryta w Zagadnieniach przyrodniczych $(30,1)$ do właściwości bachusowego trunku:

Gdy bowiem [wino] idzie do czuba, wówczas ludzie, którzy w stanie trzeźwości bywają chłodni i milczący, po wychyleniu nieco większej ilości robią się gadatliwi, po jeszcze większej ilości wielomówni i zadzierzyści; posuwając się dalej [w piciu stają się] gotowi do działania, pijąc jeszcze więcej stają się zuchwali, a wreszcie dochodzą do szału. [...] Dlatego właśnie i wino, i usposobienie [melancholiczne] mają właściwości podobne ${ }^{29}$.

nie szepnie temu,/ Co jedynie wodę pije./ Obeznany z tym, o Piotrze,/ Poświadczyć mogę najlepiej:/ Trzeźwy jestem do niczego,/ Jeśli wino mnie nie krzepi./ Wtedy namyślam się długo,/ Ociężały i bez siły,/ Tylko ogryzam paznokcie,/ Które nic nie zawiniły./ Ale gdy podchmielę sobie/ I zagrzeję winem ducha,/ Czuję, jak mi z głębi serca/ Cały pieśni tłum wybucha./ Jakby na świat wypuszczone/ Rojem wzleciały pszczoły,/ Gdy po mrozach kwieci łąki/ Ciepłej wiosny wiew wesoły".

${ }_{27}$ Por. T. Michałowska, Kochanowskiego „poeta parennis” ( $w$ kręgu renesansowych refleksji o poezji), [w:] Jan Kochanowski i epoka renesansu. W 450 rocznicę urodzin poety 1530-1580, red. T. Michałowska, Warszawa 1984, s. 61-62; taż, Poetyka i poezja, s. 169. Inaczej E. Sarnowska-Temeriusz (Droga na Parnas, s. 160-161; Renesansowe pojęcie poezji $w$ Polsce, s. 479); badaczka odmawia całkowicie naturalistycznego pojmowania inspiracji poetyckiej w ukazanym obrazie.

28 Zob. R. Klibansky, E. Panowsky, F. Saxl, Saturn i melancholia. Studia z historii filozofii, przyrody, medycyny, religii oraz sztuki, przeł. A. Kryczyńska, Kraków 2009, s. 49.

29 Arystoteles, Zagadnienia przyrodnicze, przełożył, wstępem i komentarzami opatrzył L. Regner, Warszawa 1980. Do opisanej przez starożytnego autora teorii humoralnej 
Wydaje się, iż wino, powodujące niewątpliwie pożądane pobudzenie umysłu, opisuje w wierszu Kochanowskiego wstępny etap aktu twórczego. Istotny jest jeszcze jeden komponent. Otóż pieśni, jakie wydobywają się z piersi poety pod wpływem bachusowego napoju, zachowują się $\mathrm{w}$ utworze niczym pszczoły wabione wiosennymi łąkami - poszukują kwiatów. Przedstawiony obraz może być aluzją do czynnika poezjotwórczego, którym, zgodnie z dawną teorią, była imitacja. Pszczoły w tradycji klasycznej i renesansowej symbolizowały bowiem gest twórcy ${ }^{30}$, poznającego i naśladującego istniejące wzory piękna. Plastycznie ukazana w wierszu inspiracja - kosztowanie wina - może zatem wskazywać na życiowe okoliczności, dające impuls do pisania poezji i poprzedzające proces realizacyjny.

Nie dziwi, że czarnoleski autor w swojej poezji z wina wziętej najchętniej ustanawia Bachusa bogiem natchnienia poetyckiego, dystansując się - nierzadko wprost - wobec tradycyjnej atrybucji, znanej z teorii numinalnej, która zwykła inspirację poetycką ( $\mu \alpha v i ́ \alpha)$ przypisywać $\mathrm{Mu}$ zom $^{31}$. W foricoenium pierwszym, Ad Petrum Myscoium, Kochanowski przekonuje, że właśnie bóg wina, nie zaś mieszkanki Parnasu, jest dawcą weny (w. 1-6):

Qui cenare domi Musas adeoq[ue] póéta[m] Ipsum, Myscovi no[n] reticende, vates, Accipe jure tuis foricoenia debita me[n]sis, Non Aganipaeo fonte, sed hausta cado.

Haec mihi, dum violae regnant, dum pocula spumant, Corniger occulta dicat in aure deus ${ }^{32}$.

i związanej z nią koncepcji ekscytacji nawiązują w piętnastym i kolejnych wiekach autorzy poetyk (np. G.J. Vossius, De artis poeticae ac constitutione liber, Amstelodami 1647, s. 72-73; rkps Biblioteki Czartoryskich w Krakowie, sygn. 1875, s. 6). Por. też S. Petrycy z Pilzna, Przydatki do Etyki Arystotelesowej, [w:] tegoż, Pisma wybrane, oprac. W. Wąsik, wstępem poprzedził K. Grzybowski, Kraków 1956, t. 1, s. 572. Na temat furor melancholicus zob. T. Michałowska, Poetyka i poezja..., s. 166-169.

${ }^{30}$ Dzieje toposu zob. D.C. Maleszyński, Pszczoła - „archipoeta”...

${ }^{31}$ Por. np. wypowiedź z Platońskiego Iona: „Bo wszyscy poeci, który dobre wiersze piszą, nie przez umiejętność to robią, nie przez sztukę: tylko bóg w nich wstępuje i oni w zachwyceniu wszystkie te piękne poematy mówią, a pieśniarze dobrzy tak samo" (533 e). Cyt. wg wydania: Platon, Ion, [w:] tegoż, Dialogi, przekład oraz wstęp i objaśnienia W. Witwicki, Kęty 1999, t. 1, s. 2. Zob. ponadto: Demokryt (fr. 18); Cyceron (De divinatione 1, 80; De oratore 2, 194; Pro Archia poeta 18); Horacy (De arte poetica 453 i n; 294 i n). Zob. P. Murray, Poetic inspiration in Early Greece, „The Journal of Hellenic Studies” 1981, 101, s. $87-100$.

32 Do Piotra Myszkowskiego

„Ty, co Muzom i bardziej poecie niż komu/ Wzbraniasz na samotnika biesiadować w domu,/ Przyjmij przy stole twoim powstałe dworzanki./ Nie źródła Aganippy rodzą je, 
Podmiot wiersza, zdradzając tajniki powstawania poezji, dowcipnie konstatuje, że inspiracji nie czerpie ze źródła Aganippe (non Aganipaeo fonte), lecz - co w takiej sytuacji uzasadnione - z butelki (hausta cado). Poetyckiej inicjacji towarzyszą stosowne okoliczności: rzecz dzieje się bowiem przy stole biesiadnym. Twórca wyznaje, że właśnie wtedy, gdy królują fiołki (violae regnant) ${ }^{33}$ i pienią się puchary (pocula spumant), wiersze dyktuje mu prosto do ucha (in aure) sam corniger deus, czyli Bachus, którego od starożytności przedstawiano w ikonografii z rogami ${ }^{34}$. Ów impuls do podjęcia procesu twórczego, mimo sympotycznej spontaniczności i otwartości, stanowi rodzaj wtajemniczenia, odbywa się w sekrecie (occulta). Dionizos - jako prawodawca artystycznych talentów - pojawia się ponadto w foricoenium 15: In Bacchum. Tutaj opiewany jest jako ojciec tańca oraz przyjaciel pieśni (w. 1-4):

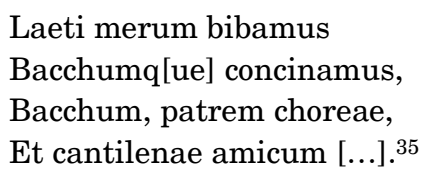

Topos boga wina, nauczyciela i przyjaciela artis poeticae, po który sięgał w swojej poezji czarnoleski twórca, był znany zarówno z literatury pięknej, jak i z uczonych traktatów. Horacy w pieśniach konstatował, iż syn Semeli jest mistrzem poetów ${ }^{36}$, a w listach zaliczał ich w poczet wyznawców rogatego boga ${ }^{37}$. Przekonanie, że wino - powszechnie uważane za symbol kultu bachicznego - powoduje u pijącego większą aktywność

lecz dzbanki./ Gdy pienią się puchary, pachną fiołków kwiaty,/ Do ucha mi je skrycie szepce bóg rogaty".

${ }^{33}$ Biesiadowaniu od czasów starożytnych towarzyszyły kwiaty, z których często przygotowywano wieńce; zob. np.: Ksenofanes (1,2); Ion (26); Alkajos (362); Safona (94,12); Anakreont (396; 397; 410); Teogonis (828).

${ }^{34}$ Zob. A. Alciatus, Emblematum libellus. Książeczka emblematów, przekład i komentarz pod kier. M. Mejora, wstęp i oprac. R. Krzywy, Warszawa 2002 (tu emblemat nr LXVII: In statua Bacchi, s. 136-137). Por. też. J. Pelc, Stowo i obraz. Na pograniczu literatury i sztuk plastycznych, Kraków 2002, s. 113.

35 „Pijmy wino, Bakchusa/ Czcząc śpiewami wesela,/ Bakchusa, ojca tańca/ I pieśni przyjaciela”.

36 „Bacchum in remotis carmina rupibus/ vidi docentem” (2, 19, 1-2). „Bakcha widziałem na skałach ustronnych,/ Jak wierszy uczył (wierzcie mi, potomni!)” (w. 1-2; przekład J. Tuwim).

37 „scriptorum chorus omnis amat nemus et fugit urbes,/ rite cliens Bacchi somno gaudentis et umbra”; 2, 2, w. 77-78). „Cała pisarzy czereda z miasta do lasów ucieka,/ Służąc Bakchowi, co rozkosz w cieniu i we śnie znajduje [...]” (w. 77-78; przekład M. Motty). Por. na ten temat ponadto: Horacy (Carmina 3, 25, 1-4 oraz cytowana już Epistula 1, 19, 3-4). 
intelektualną, uzasadniało przypisanie Bachusowi inspiracji pierwotnie uznawanej za właściwą córom Mnemosyne.

Platon zaklasyfikował szał bachiczny do kategorii „boskich”, przy czym inaczej rozdysponował atrybucje. Filozof w Fajdrosie włożył w usta Sokratesa wypowiedź charakteryzującą cztery typy furoris divini: mistyczny (dotyczył wtajemniczeń podczas zgromadzeń misteryjnych), wieszczy (występował u proroków), miłosny (u zakochanych) i poetycki (był właściwy poetom). Za szał mistyczny odpowiadał Bachus, za wieszczy - Apollo, za miłosny - Wenera, za poetycki - Muzy ${ }^{38}$. Pod wpływem koncepcji humoralnej, stawiającej na naturalistyczne czynniki natchnienia, nastąpiło jednak przemieszczenie przyporządkowań. Polski komentator Stagiryty powiada w Przydatkach do „Etyki” Arystotelesowej o szczególnym talencie melancholików: „[...] w szaleństwo wpadają, kiedy wilkość przy mózgu jest, abo się zachwyceniem myśli zaprzątną, skąd się stają Sybillae i Bacche, i wszyscy, którzy się rozumieją boskim natchnieniem pełni" 39 . Do osób uzdolnionych, pozostających pod wpływem działania czarnej żółci, zaliczył Petrycy z Pilzna obok filozofów również „poetów zmyślnych"40. Tajemniczą zależność tych ostatnich od boga wina objaśniał (łącząc naturalną i numinalną koncepcją natchnienia) Augustyn podczas rozmowy z Krystianem w Convivium profanum Erazma z Rotterdamu -

KRYSTINAN: Chciałbym cię zapytać, Augustynie, [...] dlaczego to starożytni, Bakchusa, uznawanego za wynalazcę wina, mianowali bogiem poetów? Jaki związek ten bóg-pijanica ma z poetami, czcicielami dziewięciu Muz? [...]

AUGUSTYN: [...] Fakt [...], że temu bogu hołd oddają poeci, jak przypuszczam, wyraża to, iż wino podnieca umysł i powoduje większą wymowność. Te zaś dwie rzeczy najbardziej są potrzebne wieszczom. Dlatego pełne są mrożącego chłodu pieśni, których twórcy piją tylko wodę. Natura Bakchusa wprawdzie już sama z siebie pełna jest ognia, lecz w połączeniu z darami Muz bardziej się jeszcze rozpala ${ }^{41}$.

Augustyn akcentuje niepożądaną jakość poezji wziętej z wody, a mianowicie jej przenikliwy chłód. Inaczej rzecz się ma w przypadku wierszy twórcy z Czarnolasu, inspirowanych bachusowym trunkiem. One również

38 Platon (Phaedrus 265 b; 244 a-245 a). Zob. na ten temat E. Sarnowska-Temeriusz, Przeszłość poetyki. Od Platona do Giambattisty Vica, Warszawa 1995, s. 36 . O powyższych przyporządkowaniach, występujących także w komentarzu Ficina do Platońskiej Uczty i liście Leonarda Bruniego por. tamże, s. 272.

39 S. Petrycy z Pilzna, dz. cyt., s. 572.

40 Tamże, s. 568 oraz 569.

${ }^{41}$ Cyt. wg przekładu: Erazm z Rotterdamu, Uczta na sposób świecki, [w:] tegoż, Wybór pism, wstęp i komentarz M. Cytowska, Wrocław 1992, s. 357-359. 
mają pewną, tyle że oczekiwaną, właściwość. Poeta zwykł pisać o swojej łacińskiej muzie, określając ją epitetem blandus. Kategoria ta wyraża, niekiedy trudny do zdefiniowania, powab, wdzięk mowy wiązanej. O poezji „tchnącej niewysłowionym czarem” (nescio quid blandum spirans) wspominał Kochanowski w Liście do Stanistawa Fogelwedera, gdy był zmuszony wybierać między zjawiskową i tajemniczą, upersonifikowaną Poetyką a nakazami reguł sztuki, obrazowanymi przez gwoździe i kliny, dzierżone w rękach przez Ananke ${ }^{42}$. Właściwą decyzję czarnoleski wieszcz łączył z „podszeptem” bóstwa, które w antycznej tradycji odpowiada za afekty i nierzadko towarzyszy Dionizosowi. Chodzi o boginię miłości i matkę Amora.

W cytowanych już Przydatkach Petrycy z Pilzna konstatuje za Stagirytą: „[...] Wino chęć do Wenery zapalić może. Przeto nie bez przyczyny Wenerę z Bacchem złączoną malują, iż melancholicy po więtszej częśsi zbytnie do wszeteczeństwa prętcy [...]"43. W elegii 1,1 czarnoleskiego twórcy mowa o miłości, Amorze. Gdy poeta po raz kolejny przekonuje, iż czynnikiem warunkującym pisanie nie są parnaskie boginie, ponieważ wcale nie zachodził do aonijskiej groty („Non me, si modò sum, Musae facêre póétam, / Nec memini Aoniae rupis adisse specus"; w. 1-2), stwierdza także (w. 3-6):

Solus amor docuit blandos me fingere versus

Et canere antiquo consona Callimacho.

Ille deus segnes animos, et inertia corda,

Ingenium torpens excitat ille deus ${ }^{44}$.

Źródłem aktu twórczego jest miłość (solus amor), która stanowi impuls niemal porównywalny do natchnienia pochodzącego od bóstwa (o czym zdaje się świadczyć dwukrotnie powtórzone sformułowanie: ille deus $)^{45}$. Żarliwe uczucie rozbudza (excitat) leniwe umysły i zimne serca.

42 J. Kochanowski, List do Stanisława Fogelwedera, [w:] Dzieła polskie, t. 3, s. 275-278.

${ }^{43}$ S. Petrycy z Pilzna, dz. cyt., s. 570-571.

44 „Jeślim poetą, dziełem to nie Muz jest wcale,/ Nie chodziłem do groty w aonijskiej skale,/ Jeno miłość uczyła mnie wiersz składać słodki,/ Naśladując starego Kallimacha zwrotki./ Albowiem bóg miłości umysły ospałe,/ Serca zimne podnieca i dusze zdrętwiałe”.

45 E. Sarnowska-Temeriusz (Renesansowe pojęcie poezji w Polsce..., s. 480) mówi o pozbawionym cech boskości, jednak pozarozumowym, uniesieniu. Podkreśla (taż, Droga na Parnas, s. 160) płynność między zapamiętaniem miłosnym a szałem poetyckim. Por. też T. Michałowska, Kochanowskiego „poeta parennis” ( $w$ kręgu renesansowych refleksji o poe$z j i)$, s. 60-61. O artystycznych „konsekwencjach” miłosnego zauroczenia wspomina poprzednik Kochanowskiego na niwie poezji elegijnej - Klemens Janicjusz. Autor w elegii jedenastej z księgi Variarum elegiarum liber I (wyd. cyt.) napisze o dwóch jednoczesnych darach matki Amora: „nemo nisi mater Amoris/ In mea conveniens carmina novit opus./ 
Również tu pojawia się sygnał sugerujący, że na powstawanie czarujących wierszy (blandos versus) mają wpływ zarówno czynniki fizjologiczne, jak i intelektualne. Zdaniem czarnoleskiego mistrza następstwem należącego do fazy przeżyciowej impulsu jest bowiem proces realizacyjny sprawność polegająca na naśladowaniu (fingere) stosownych, zwłaszcza klasycznych, wzorców (canere antiquo consona Callimacho).

Bóg wina i jego groźny atrybut - róg - zdają się być w poezji Kochanowskiego ostatecznie silniejsze... nawet od samej miłości, gdyż cornus Bachusa staje się środkiem, przed którym musi uciekać sam potężny Amor. W elegii 2, 2 poeta przypomina, że jest wiernym piewcą boga wina (tuus vates, w. 1). W zamian za to doprasza się pewnych względów: błaga, aby syn Semeli uwolnił swego sługę od doskwierających mu miłosnych upałów. Wszak - jak poucza Euenos - boski napój nie tylko wznieca uczucia, lecz także może je gasić, bo „Kiedy [...] pachnie zbyt mocno uśmierza miłosne zapały,/ W śnie nas jedynie pogrąża [...]"46. Wino, zwłaszcza wyborne, spełnia u autora Fraszek jeszcze jedną, bodaj najistotniejszą metapoetycka funkcję.

\section{Pijane rymy}

Pośród utworów Kochanowskiego odrębną, trzecią grupę stanowią wybrane sympotyczne teksty, w których dyskurs poświęcony piciu wody i wina służy poecie do zaakcentowania kryterium oceny (głównie cudzej) poezji, będącej źródłem przeżycia estetycznego i twórczej inspiracji. Pisarz kreuje w tym celu alegoryczne obrazy, używając biesiadnym kodu.

Warto zwrócić uwagę na często pojawiający się w twórczości mistrza z Czarnolasu sympotyczny obraz poetów, którzy nierzadko piją wino i chętnie oceniają jego jakość: delektują się nim, zachwalając, bądź też wyrażają dezaprobatę wobec złego smaku. Kochanowski, pisząc o piciu przez nich wina, sugeruje niejednokrotnie, że mówi wówczas o poezji, jej odbiorze oraz wartościowaniu. Wypowiedzi takie mają zatem charakter sądów metakrytycznych.

By sobie $\mathrm{w}$ pełni uświadomić mechanizm związany $\mathrm{z}$ użyciem biesiadnego kodu, należy uchwycić pewne semantyczne transpozycje w sym-

Haec mihi formosam dignamque Helicone puellam/ Si dederit, blando carmine quantus ero!” (w. 15-18). „Jedynie matka Amora wie, co jest odpowiednią treścią dla moich pieśni. Jeśli ona ześle mi dziewczynę piękną i godną Helikonu, jakże czarujące zanucę pieśń!”. Również tutaj nie Muzy, lecz muza-kochanka i pochodzące od Wenery uczucie stanowią impuls do podjęcia twórczości literackiej (w. 15-18).

${ }^{46}$ Euenos 2, [w:] Liryka starożytnej Grecji..., s. 344. 
potycznej twórczości autora Pieśni; po pierwsze, że pijany (ebrius) znaczy 'natchniony', a pić $\rightarrow$ 'smakować poezję'. Po drugie, iż dobra poezja to 'wino', zaś poezja słaba $\rightarrow$ 'woda'. Po trzecie - zmysł smaku (sensus) i związana z nim terminologia (np. „podniebienie”, palatum), odnosząca się do percepcji, określają literacką ocenę i gust estetyczny.

Taki sposób poetyckiego obrazowania, zasadzający się na związkach między terminologią sympotyczną a poetycką, znany był już antycznym autorom greckim. Pisze badaczka literatury hellenistycznej Krystyna Bartol: „Grecy uznawali, iż między sztuką poetycką a kulinarną istnieje swego rodzaju artystyczne powinowactwo, jako że jedna i druga stanowią rodzaj $\tau \dot{\chi} \chi v \eta$ i opierają się na pewnych założeniach (posiadają pewien voṽ), których wypełnienie wymaga od realizatora opanowania pewnych umiejętności" 47 . Występujące na przykład w szóstej odzie istmijskiej Pindara mieszanie krateru pieśni podczas uczty sugeruje, że wino i poezja tworzą unię, skoro poeta mówi nie o mieszaniu wina $\mathrm{z}$ wodą - jak grecki obyczaj nakazywał - lecz wina i pieśni: „Jak w rozkwicie biesiadnej mężów wesołości,/ Drugi mieszamy pieśni Muz krater/ Na pomyślność sławnego z atletów domu Lampona [...]" (w. 1-3)48. Metaforyka tego typu pojawia się również u innych twórców starożytnej Hellady, by wymienić choćby myśl pochodzącą $\mathrm{z}$ anonimowego anakreontyku, która również odnosi się do starożytnego biesiadnego obrzędu mieszania wina i wody: „Słodko śpiewa Anakreont, / Słodko śpiewa też Safona,/ Lecz wraz z nimi pieśń Pindara/ Wymieszajcie w moim dzbanie" (w. 1-3) ${ }^{49}$, czy też - przenośne sformułowanie Dionysiosa Chalkusa: „Hymny nalewać jak wino" (w. 1) ${ }^{50}$.

Foricoenium 74: Ad Heliodorum Kochanowskiego to wspomnienie uczty, jaka odbyła się u adresata utworu.

47 K. Bartol, Smakować poezję. „Gastronomia literacka” w wypowiedziach greckich poetów lirycznych, [w:] Litteris vivere. Księga pamiątkowa ofiarowana profesorowi Andrzejowi Wójcickowi..., s. 32-33. Na ten temat zob. ponadto: taż, Uczta u Heliodora (Lukillios A. P. 11. 137), [w:] Epigram grecki i taciński w kulturze Europy, Konferencja ogólnopolska. 11-12 grudnia 1995, red. K. Bartol i J. Danielewicz, Poznań 1997, s. 91-99; M. Wesoły, dz. cyt., s. 43-55; S. Nannini, Simboli e metafore nella poesia simposiale greca, Roma 1988, s. 19-35; M. Pizzocaro, Alcmane e la gastronomia poetica, „AION” 1990, 12, s. 285-308.

48 Pindar, Isthmiae 6, [w:] tegoż, Ody zwycięskie, olimpijskie, pytyjskie, nemejskie, istmijskie, przekł., wstęp komentarz M. Brożek, Kraków 1987, s. 60.

49 Anakreontyki 20, [w:] tamże, s. 117. Por. też inne przykłady sympotycznego sposobu przedstawiania poezji: Pinadar, Nemeae 3, 76 n.; Olympiae 6, 87-91 („Tyś słodkim naczyniem mieszalnym rozbrzmiewających głośno pieśni”, przekład K. Bartol); scolion $917 \mathrm{~b}, 1-2$.

50 Dionysios Chalkus 4, [w:] Liryka starożytnej Grecji..., s. 343. 
Heliodore, fides esset si incerta palati

Et falli sensus posse aliquando putem,

Quae tu vina vocas, latices ego dicere fontis

Ausim, quem volucris pes patefecit equi

Olim summo Helicone: ita Musis ebrius à te

Discedo semper, carminibusq[ue] tumens ${ }^{51}$.

To, co dla Heliodora jest winem (tu vina vocas), dla poety, który wraca „podpity” z uczty, jawi się jako woda z tego samego źródła (latices ego fontis), jakie odkrył niegdyś kopytem skrzydlaty koń (volucris pes patefecit equi). Literat opiera swoje estetyczne rozpoznanie na ufności w smak (falli sensus) i własne podniebienie (incerta palati), a te zawieść nie mogą. Dobrze wie zatem, że impulsem poetyckim nie była woda z helikońskiego strumienia. Owszem, przyznaje, iż nazwałby nią chętnie to, co go natchnęło, ale jedynie ze względu na analogiczne właściwości. Podmiot mówi o upojeniu (ebrius) i wypełniających go Muzach, które - warto zauważyć - użyte tu w znaczeniu metonimicznym, oznaczają twórczość (zapewne uświetniającą towarzyskie spotkanie).

Kochanowski wykorzystał semantyczny potencjał tkwiący w biesiadnym obrazie, czyniąc artystyczny pożytek z sensualnego pojęcia smaku (sensus), który w estetyce utożsamiany był z bliską mu kategorią „gustu” i łączony z sądem krytycznym (iudicium) ${ }^{52}$. Według stoików o wartości estetycznej sądzą zmysły (oczy i uszy), nie zaś rozum. Cyceron pojmował sensus jako zmysł piękna, właściwy tylko człowiekowi, pozwalający mu ocenić, co jest w sztuce słuszne, a co błędne (De oratore 3, 50, 195). Zdaniem starożytnego mówcy smak, czyli wyczucie, to dar natury (Orator 55, $183)^{53}$. Kategoria dobrego gustu, buon giudizio, pojawiła się także w re-

${ }^{51}$ Do Heliodora

„Gdyby nie w podniebienie ufność, Heliodorze,/ I pewność, że mnie żaden zmysł zawieść nie może,/ Co ty winem, krynicą nazwałbym pod szczytem/ Helikonu odkrytą pegaza kopytem,/ Tak dalece przez Muzy jestem upojony,/ Kiedy od ciebie wracam pieśniami natchniony".

52 B. Otwinowska zauważa, że kontaminacja pojęć jest wynikiem uznania pluralizmu w zakresie sądów estetycznych, jaki nastąpił głównie pod wpływem myśli włoskiej w wieku XVI. Por. B. Otwinowska, Iudicium, [hasło w:] Stownik literatury staropolskiej, red. T. Michałowska, przy współudziale B. Otwinowskiej, E. Sarnowskiej-Temeriusz, wyd. 3, bez zmian, Wrocław 2002, s. 355.

53 Por. także Cyceron, De officilis 1, 4, 14. Terminem smak (sensus / gustus) posługują się sporadycznie także: Horacy (Satirae 1, 3, 66), Kwintylian (Institutio oratoria 6, 3, 17) i Petroniusz (Satiricon). Na temat pojęcia gustu/ smaku zob. szerzej: S. Pazura, De gustibus. Rozważania nad dziejami pojęcia smaku estetycznego, Warszawa 1981; T. Kostkiewiczowa, Krytyka literacka $w$ Polsce $w$ epoce oświecenia, [w:] E. Sarnowska-Temeriusz, 
nesansowych Włoszech między innymi w aspekcie używania w języku literackim dawnych słów toskańskich. Sprowadzała się przede wszystkim do pytania o kryteria literackiego osądu (i wyboru), a mianowicie: o to, co „wyuczalne" (reguły i studia), i to, co wrodzone, właściwe jedyne artyście (naturalne umiejętności, ingenium) 54 . Zapewne w kontekście owych nowożytnych europejskich debat należy odczytywać niektóre sympotyczne wiersze polskiego autora.

W przenośnym znaczeniu, związanym z oceną literacką, „smak” występuje także w wybranych polskojęzycznych utworach Kochanowskiego. O poetyckim guście, wyraźnie zdradzającym predylekcje do klasycznych reguł, mówi autor we fraszce 3, 74, zatytułowanej Do starosty Muszyńskiego. Koncept opiera się tu na grze znaczeń dwóch fraz: „znać się dobrze na winie” i „mieć smak staradawny”:

\author{
O starosta na Muszynie \\ Ty się znasz dobrze na winie; \\ Znasz i masz; bo tylko z góry \\ Spuściwszy wóz, aliż Uhry. \\ Okaż swój smak staradawny, \\ Starosto Muszyński sławny, \\ A niech go ja skosztuję, \\ Boć i ja smak w beczce czuję. \\ A nie żal mi, żem poetą, \\ Jest coś umieć alfę z betą. \\ Tym ludziom, ty Stanisławie, \\ Chcesz li się zachować prawie, \\ Nie szafirem, nie rubinem, \\ Ale je ćci dobrym winem. \\ A stąd to będziesz miał w zysku, \\ Że coś dziś obłoków blisku, \\ To cię pijanymi rymy \\ Aż do nieba wprowadzimy.
}

T. Kostkiewiczowa, Krytyka literacka $w$ Polsce $w$ XVI $i$ XVII wieku oraz $w$ epoce oświecenia, Wrocław 1990, s. 177-179.

54 O kategorii „dobrego smaku”/ bon giudizio w renesansie por. M. Wojtkowskiej-Maksymik, „Gentiluomo cortegiano” $i$ „dworzanin polski”. Dyskusja o doskonatości człowieka $w$ „Il Libro del cortegiano Baldassarra Castiglionego i „Dworzaninie polskim” Eukasza Górnickiego, Warszawa 2007, s. 148-163. Oba terminy, gust i smak, pojawiały się ponadto w późniejszych dyskusjach, dotyczących autorytetu literatury starożytnej, jakie toczono we Francji (Querelle des anciens et dens modernes) a także w Anglii (The Battle of the Books); zob. B. Otwinowska, dz. cyt., s. 355. 
Poeta za pomocą sformułowania: „Ty się znasz dobrze na winie” chce komplementować starostę ${ }^{55}$ za to, że jest wytrawnym znawcą klasycznych kanonów piękna - przejawia „smak staradawny”. Do posiadania podobnych umiejętności przyznaje się i sam nadawca („Boć i ja smak w beczce czuję"...), i dodaje jednocześnie, określając swoje poetyckie kompetencje minimalizująco: „A nie żal mi, żem poetą,/ Jest coś umieć alfę z betą". Owa biegłość w sztuce poetyckiej nie pojawiła się tu jednakże przypadkowo (nie byłaby przecież potrzebna do tego, aby smakować trunek...). Poeta chce przede wszystkim poznawać gust i umiejętności literackie starosty.

Zachęta, by Muszyński, podejmując wyjątkowych gości, „ćcił dobrym winem”, jest zapewne sugestią, aby pan domu czytał własne poezje. Warto zauważyć pewną grę słowną, jaka może ukrywać się za określeniem „ćcić”. Otóż czasownik ćcić ma wspólny źródłosłów z czasownikiem czyść pierwszy oznaczał 'gościć' (ćcić, stąd u-ćcić i uczta), drugi - 'czytać' (czyść, od tego czcienie i późniejsze czytanie); tak było jeszcze w szesnastym wie$\mathrm{ku}^{56}$. Powyższe sformułowanie może być aluzją do formy prezentacji poezji, jaką jest właśnie czytanie, głośna lektura. Podobny koncept zastosował we fraszce trzeciej, Do gościa, Melchior Pudłowski, zestawiając oba czasowniki: czyść i ćcić. Poeta obiecywał podejmowanemu gościowi: „przeczczę co śmiesznego tobie" (w. 3) i tłumaczył, że w swoich skromnych progach będzie „więcej czytać niż ćcié” (w. 5) ${ }^{57}$.

Owo wyborne „wino” ma być najstosowniejszym - przekonuje podmiot - poczęstunkiem dla poetów: „Tym ludziom, ty Stanisławie,/ Chcesz li się zachować prawie,/ Nie szafirem, nie rubinem,/ Ale je ćci dobrym winem”. Z kolei twórcy za literackie „uczczenie” obiecują odwdzięczyć się gospodarzowi toastem - oczywiście w postaci „pijanych rymów”. Taki sposób okazywania wdzięczności i określania poetyckiego przypijania znała grecka literatura sympotyczna. „O Teodorze, ten toast w wiersze ujęty ode mnie/ przyjmij; najpierw ku tobie w prawą stronę kieruję/ kielich poezji, dodawszy wdzięku wytwornych Charyt" - pisał, dedykując współbiesiadnikowi swój wiersz, Dionizos Chalkos ${ }^{58}$. Podobnie czy-

${ }^{55}$ Niewiele wiadomo o samym adresacie fraszki, którym, wedle wskazań badaczy, był Stanisław Kępiński. Polski stownik biograficzny nie odnotowuje biogramu starosty (por. t. 12: Kapostas Andrzej-Klobassa Zręcki Karol, Wrocław 1966-1967, passim).

56 Zob. W. Boryś: Słownik etymologiczny języka polskiego, Kraków 2005, s. 662; Słownik polszczyzny XVI wieku, red. S. Bąk, S. Hrabec, W. Kuraszkiewicz [i in.], Wrocław 1969, t. 4, s. 359-361 (czyść/ czcić/ tcić/ ćcić = czytać); s. 110-113 (czcić/ ćcić/ tcić/ tczcić = wielce szacować, też = gościć).

57 M. Pudłowski, Fraszek księga pierwsza, [w:] tegoż, Pisma, wyd. T. Wierzbowski, Warszawa 1898, s. 30.

58 Dionysios Chalkus 1, w. 1-3, [w:] Liryka starożytnej Grecji, s. 342. 
nił Pindar w swoim enkomionie: „Ten rydwan słodkich pieśni, Trasybulu,/ Posyłam ci na deser, aby w waszym kole/ Słodką podnietą był dla biesiadników [...]" (w. 1-3)59.

Bywa jednak, że nie każdy wiersz ma smak dobrego wina, lecz zyskuje jakość zbliżoną do wody. Często pojawiającym się zabiegiem w twórczości czarnoleskiego poety, związanej z biesiadną techniką obrazowania, jest utożsamianie świetnej poezji $\mathrm{z}$ dobrym winem, zaś słabej - $\mathrm{z}$ wodą. Wypowiedzi te nabieraja zatem charakteru krytycznoliterackiego. Za przykład niech posłuży foricoenium 20: Ad Ibicum:

\author{
Si coenitare vis poetas, et crebro \\ Potare apud te, pol, sapientis, Ibyce, \\ Homines palati, pocula haec lymphatica, \\ Merumq[ue] flumen amoveri fac procul \\ Servis bibendum sobriaeq[ue] virgini. \\ Nobis Falernum ardentiusq[ue] Caecubum \\ Capocioribus jube adponi scyphis, \\ Nam si bibendum est, optimum quodq[ue], Ibyce, \\ Vinum bibendum est, caetera esto sobrius ${ }^{60}$.
}

Należy zauważyć, że uczestnikami biesiady mają być nieprzeciętni goście - wyłącznie literaci, którzy nazwani są ludźmi o wybrednym podniebieniu. Poeta zachęca, aby gospodarz zachował wodę dla domowej czeladzi, a twórcom podał wyborne wino. Domagając się dobrego trunku, określa jego gatunki oraz wielkość pucharów, w jakie ma być wlany. Autor twierdzi, że jeśli ma być pite wino, to tylko dobre, w przeciwnym wypadku - lepiej pozostać trzeźwym.

Wypowiedź należy odczytać jako dość śmiałą dezyderatę dotyczącą jakości dania poetyckiego, które gospodarz zaserwuje podczas uczty. Podmiot chce przede wszystkim powiedzieć, że słaba literatura (merum flumen) nadaje się dla niewybrednych odbiorców (wszak tym smak literacki jest obcy), a poeci, jako goście posiadający wyjątkowy gust poetycki (palatum), oczekują dobrej poezji (optimum vinum). Zapewne dorównującej tej, jaką czytywał (vel pijał...) Horacy na ucztach rzymskich u Mece-

59 Pindar, fr. 124 a-b [Enkomion dla Trasybulosa z Akragantu], przekł. A. Szastyńska-Siemion, [w:] tamże, s. 196. Zob. ponadto: tenże, Nemeae 3, 76 n.; Olympiae 7, 1-10, Kritias 4. Por. na temat tych miejsc: K. Bartol, Smakować poezję..., s. 36-40.

${ }^{60}$ Do Ibika

„Jeżeli chcesz, Ibiku, by poeci mili/ Często u ciebie jedli i wesoło pili,/ Pamiętaj, że wybredne mają podniebienia./ Więc precz z tą rzadką lurą, wodą ze strumienia,/ Niechaj ją pije z dziewkami skromnymi twa czeladź./ Na Polluksa, innego napitku nam nie lać,/ Tylko Falern z Cekubem niech w nas niecą żary/ I rozkaż, aby spore podano puchary./ Jeśli pić, to najlepsze wina każ wydostać,/ A jeśli nie, Ibiku, lepiej trzeźwym zostać”. 
nasa. Nieprzypadkowo pojawiają się tu nazwy win znane starożytnym, a szczególnie często występujące na kartach pieśni rzymskiego poety, a mianowicie Falernum i Caecubum ${ }^{61}$. Prośba o spore puchary, również występująca tak często w starożytnej literaturze biesiadnej ${ }^{62}$, ma tu wyrażać pragnienie, aby poezji podczas tej uczty prezentowało się szczególnie dużo. Dwa ostatnie wersy to z kolei refleksja dotycząca korzyści płynących z uczonej biesiady. Zdaniem autora, delektowanie się podczas uczty tylko dobrą twórczością zagwarantuje satysfakcję i zainspiruje wyjątkowych uczestników spotkania. W innym razie nie wywoła tak pożądanej przez nich ekscytacji (esto sobrius).

Skoro biesiadna poezja, umilająca towarzyskie spotkanie, niejednokrotnie zastępuje wino, nie jest chyba zaskoczeniem, że sympotyczne upojenie to nierzadko trzeźwe pijaństwo. Zdarza się - jak przekonuje Kochanowski - iż twórca (i uczestnik uczty) miewa wątpliwości, co było przyczyną upojenia: wino, a może poezja? Sytuację taką opisuje fraszka 3, 64, zatytułowana Do Wacława Ostroroga:

\footnotetext{
Próżno przeć, upiłem się: winem? czy-li rymy? Jeśli winem, subtelne tego wina dymy. Wiesz, co mi się teraz zda, Wacławie cnotliwy? Zda mi się, że maluję swój obraz właściwy, Który miedzy biskupy zawieszę zacnymi, Nie wsiami światu znaczny, ale rymy swymi. Wszyscy pijani, widzę, a pijanem i ja: Kto szczęściem, a ja winem; odpuść Adrastyja.
}

Dylemat poety, wyrażony w incipicie: „upiłem się: winem? czy-li rymy?", jest w gruncie rzeczy pozorny - ponieważ odpowiedź przynosi już wers kolejny. W zdaniu warunkowym zawarta została sugestia o małym prawdopodobieństwie alkoholowego upojenia („Jeśli winem, subtelne tego wina dymy"). Biesiadna figura opiera się na nadaniu przenośnego znaczenia czasownikowi „upiłem się", który w powszechnym użyciu występuje jako określenie stanu oszołomienia wywołanego trunkiem, jednak po

61 Falernum to wino z miejscowości Falernum w Kampanii. Wśród znamienitych włoskich win wymienia je Atenajos w Uczcie mędrców (1, 33 a), jednak najbardziej rozsławione zostało w rzymskiej poezji Horacego; (Carmina 1, 27, 10; 2, 3, 8; 2, 11, 19; 3, 1, 43). Caecubum opiewa Horacy w carmen 3, 28, 3. Na temat wina, jego funkcji i gatunków w poezji Horacego zob. też J. Krókowski, Wstęp, [w:] Horacy, Wybór poezji, oprac. J. Krókowski, Wrocław 2007, s. XXIII-XXIV.

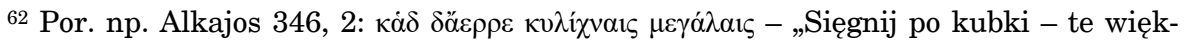
sze" (cyt. oryg. wg wyd.: Greek lyric, [t.] 1: Sapho and Alcaeus, with an english translation by D.A. Campbell, Cambridge, Mass. - London 1988, s. 378, przekład - wg wyd.: Liryka starożytnej Grecji..., s. 68). 
przeniesieniu w sferę literacką zyskuje przenośne znaczenie, mianowicie określa stan ekscytacji, uniesienia, spowodowanego poezją. Ten - jak mówi Kochanowski - „obraz właściwy” poety „nietrzeźwego”, upojonego literackim winem, zasługuje na umieszczenie „miedzy biskupy”. Na poczet przyszłej sławy księcia poetów składać się ma właśnie owa pijana twórczość.

Kategoria ebrietas, pojmowana jako trzeźwe pijaństwo ${ }^{63}$, jest niezwykle chętnie wykorzystywana przez Jan z Czarnolasu, szczególnie w łacińskiej książeczki epigramatów. W foricoenium 64 , znajdującym się niemal w połowie zbioru, tłumaczy on, że kolekcja nie realizuje w pełni tego, co głosi jej tytuł, ponieważ mecenasi nazbyt rzadko zapraszają na uczty, więc autor musi, biesiadując samotnie, w zaciszu domowym pisać wiersze. Kochanowski przekonuje przy tym, że owo prywatne ucztowanie i tworzenie foricoeniów jest dla niego tym samym, czym śpiewanie pijanych piosenek po kubku wody („Nam coenare domi, et foricoenia scribere, tantum est,/ Ac si ad aquae cyathos ebria verba sones"; Ad lectorem, w. 7-8)64. Tworzenie pijanych poezji (ebria scriptalebria verba) pod wpływem wody nie jest możliwe, ponieważ tworzenie literatury, jak już wiadomo, wymaga dobrego wina, czyli odpowiedniej inspiracji, jaka zapewnia kontakt ze znakomitymi, zwłaszcza opartymi na klasycznych kanonach piękna, tekstami.

Próżno szukać w całej (nie tylko epigramatycznej) spuściźnie czarnoleskiego mistrza wzmianki o kosztowaniu wody ze świętego źródła, któremu przypisywałoby się właściwości inspirujące. Nigdzie też - w myśl takiej koncepcji inicjacji poetyckiej - nie mówi się o Muzach jako o dawczyniach natchnienia poetyckiego. W wierszu Do Muz $($ Fraszki 2, 1) poeta kieruje taką apostrofę do opiekunek sztuki:

Panny, które na wielkim Parnazie mieszkacie, A ippokreńską rosą włosy swe maczacie, Jeślim się wam zachował jako żyw statecznie, Ani mam wolej z wami rozłączyć się wiecznie; Jeśli królom nie zajźrzę pereł ani złota, A milsza mi daleko niż pieniądze cnota; Jeśli nie chcę, żebyście komu pochlebiały Albo na mię u ludzi niewdzięcznych żebrały; Proszę, niech ze mną zaraz me rymy nie giną, Ale kiedy ja umrę, ony niechaj słyną.

63 Szerzej na temat tej kategorii rozpoznanej w literaturze antycznej zob. H. Lewy, Sobria ebrietas. Untersuchunden zur Geschiche der antiken Mystik, Giessen 1929.

${ }^{64}$ „Bo w domu jeść i pisać fraszki, to jak dzięki/ Kubkowi wody śpiewać pijane piosenki”. 
Boginie zraszają swoje włosy $\mathrm{w}$ rosie Hipokrene. Poeta nie pije $\mathrm{z}$ ich zdroju ani nie prosi o natchnienie. Chce natomiast powiedzieć, że pragnie, aby po śmierci trwała u potomnych pamięć o jego poezji. Podobne wyznanie czyni Kochanowski w łacińskiej elegii siódmej z księgi trzeciej („Tu, quoq[ue] si fas est, cùm, me mea fata vocabunt,/ Haec superesse mihi carmina, Musa, velis [...]”, w. 5-6)65, a pełniejsze rozwinięcie tej myśli przynosi poemat Muza (w. 19-36):

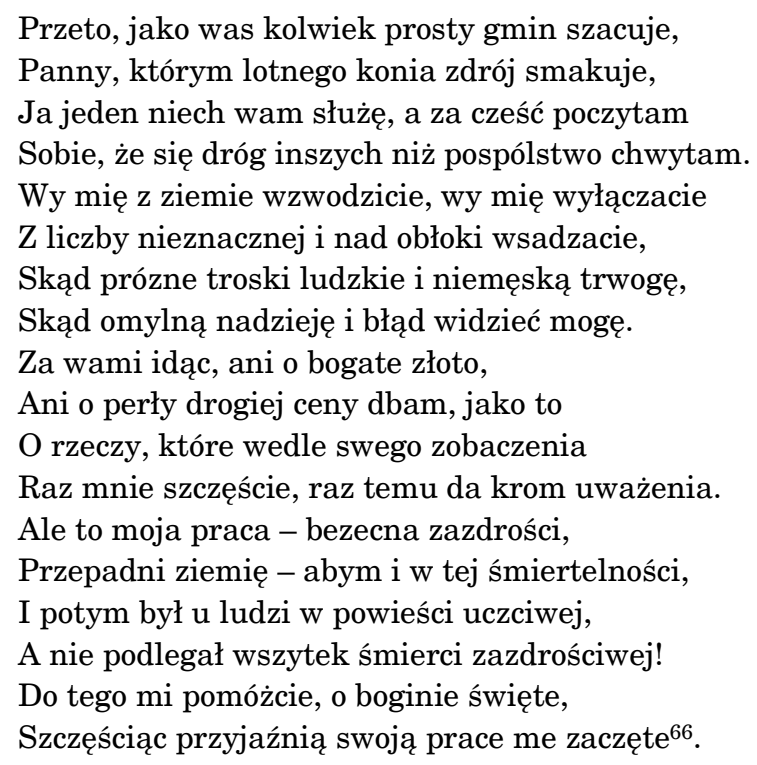

Córki Mnemosyne, które same pijają ze zdroju Pegaza, mają zapewnić autorowi nieśmiertelność i nieprzemijającą sławę. Mają - przede wszystkim dzięki literackim formom reprezentacji - sprawić, iż poeta nie będzie kiedyś - by posłużyć się sformułowaniem z Trenu IX - „miedzy insze, jeden z wiela, policzony". Taka, przynosząca przyszłe uobecnienie, rola przypadła mieszkankom Parnasu w poezji Jana z Czarnolasu.

W procesie twórczym, zdaniem autora Fraszek, udział mają zdobyte doświadczenie i znajomość prawideł poetyki. Nie są one jednak wystarczające. Antyczny topos wina i wody umożliwił poecie odsłonięcie artystycznego zamysłu, jaki pisarz starał się realizować w swojej twórczości, postępując przede wszystkim za naturalnym smakiem. To z kryterium jednostkowego gustu Kochanowski łączy wybór stosownych źródeł natchnienia (resp. entuzjazmu) i właściwy literacki osąd (iudicium). Autorme lata".

65 „Więc, Muzo, gdy odwoła mnie los z tego świata,/ Spraw, aby pieśni moje przeżyły

${ }^{66}$ Cyt. wg wydania: J. Kochanowski, Dzieła polskie..., t. 1. 
ski sąd wydaje się niezastąpiony zarówno w ocenie twórczości innych, jak i we własnych pisarskich rozterkach, zwłaszcza wtedy, gdy zachowanie równowagi między nakazami reguł a powabem piękna okazuje się niesatysfakcjonujące.

Smak - ujmowany przez czarnoleskiego mistrza w biesiadnej topice tyleż estetycznie, co i sensytywnie - jest wiedzą zmysłową, a zatem subiektywną i niełatwą do sprecyzowania. Odczuwając przyjemność obcowania $\mathrm{z}$ pięknem, trudno przecież wyrazić jego istotę. Jednakowoż w przeżyciu estetycznym tkwi element oceny, tyle że nie ma ona charakteru abstrakcyjno-dyskursywnego, lecz emocjonalny. Prawdziwa poezja, blanda carmina - sugeruje Kochanowski - to pochodna impulsów płynących z otaczającego świata, „wino” bezpośrednio z życia wzięte i płód pobudzonej działaniem afektów wyobraźni. Autor wskazuje przy tym na okoliczności, które dodają mu weny, napełniając go „naturalnym pijaństwem". Zalicza do nich: doznania płynące z obcowania z cudzą twórczością, miłość, a także „dobrą myśl” biesiadną.

Indywidualny smak ma wspierać poetę również $\mathrm{w}$ wyborze $\mathrm{z}$ bogatego skarbca tradycji tego, co najwartościowsze. Prawdą jest, iż gusta mistrza z Czarnolasu zdradzają predylekcję do wytrawnych, nierzadko starożytnych trunków, które - jak sam chętnie przyznaje i o czym wiadomo skądinąd - inspirują jego polską i łacińską poezję. Wzory klasyczne nie są wszakże nigdy wędzidłem, lecz probierzem oraz punktem odniesienia. Kochanowski za pomocą konwiwialnych obrazów artykułuje zdystansowanie w stosunku do „wodopijców” - tych współczesnych, których twórczość, jak można przypuszczać, nie posiadała „życiowopochodnych” właściwości i nie zawsze była w stanie sprostać renesansowym teoriom emulacji (a te przecież stawiały sobie za cel nie tylko naśladowanie klasyków, lecz zwłaszcza współtworzenie i wzbogacanie zastanych kanonów piękna).

Zaczerpnięte przez Kochanowskiego z literatury sympotycznej zmysłowe obrazowanie jakości poezji i związanych z nią czynności poznawczych wydaje się dalekie od rozwiązań sugerowanych w renesansowych poetykach. Wyrażanie za pomocą symboli sensualnych abstrakcyjnych właściwości estetycznych wkrótce podejmie liryka baroku. W twórczości autora Pieśni - poszukującej w zmysłowych obrazach nowych form ekspresji oraz akcentującej rangę jednostkowego wyczucia piękna - budzi się estetyka kolejnej epoki. Nieskrępowana wyobraźnia poetycka, ale i niebywała intuicja, zdają się prowadzić czarnoleskiego wizjonera i praktyka do punktu, w którym odrodzi się nurt klasycystyczny - zdecydowanie bardziej stawiający akcent na jednostkowy gust, aniżeli na gotowe rozwiązanie. 


\section{BIBLIOGRAFIA}

Alciatus, Emblematum libellus. Ksią̇eczka emblematów, przekład i komentarz pod kier. M. Mejora, wstęp i oprac. R. Krzywy, Warszawa 2002.

Arystoteles, Zagadnienia przyrodnicze, przełożył, wstępem i komentarzami opatrzył L. Regner, Warszawa 1980.

Atenajos, Uczta mędrców, przeł., wstępem i przypisami opatrzyli K. Bartol (księgi I-II, VI-VII, XI-XII, XIV, XV 665 a-686 c) i J. Danielewicz (księgi III-V, VIII-X, XIII, XV 686 d-702 c), Poznań 2010.

Bartol K., Smakować poezję. „Gastronomia literacka” $w$ wypowiedziach greckich poetów lirycznych, [w:] Litteris vivere. Księga pamiatkowa ofiarowana profesorowi Andrzejowi Wójcikowi, red. I. Lewandowski, K. Liman, Poznań 1996, s. 31-41.

Bartol K., Uczta u Heliodora (Lukillios A. P. 11. 137), [w:] Epigram grecki i taciński w kulturze Europy, Konferencja ogólnopolska. 11-12 grudnia 1995, red. K. Bartol, J. Danielewicz, Poznań 1997, s. 91-99.

Boryś W.: Stownik etymologiczny języka polskiego, Kraków 2005.

Brzozowski J., Muzy w poezji polskiej. Dzieje toposu do przełomu romantycznego, Wrocław 1986.

Catullus Q., Carmina, recensuit E. T. Müeller, Lipsiae 1919.

Crowthera N.B., Water and Wine as Symbols of Inspiration, „Mnemosyne” 1979, 32, nr $1 / 2$, s. $1-11$.

Dantyszek J., Pieśni, wybór i tłum. A. Kamieńska, wstęp Z. Nowak, wyd. 2, zmienione, Olsztyn 1985.

Erazm z Rotterdamu, Biesiada na sposób świecki, [w:] tegoż, Wybór pism, wstęp i komentarz M. Cytowska, Wrocław 1992, s. 352-380.

Frost Ch.P., Propertius 3.3.45: Don't Go Near the Water, Baltimore, ML, 1991, 112, nr 2, s. 251-259.

Greek lyric, t. 1-2, with an English translation by D.A. Campbell, Cambridge, Mass. - London 1988.

Hanford J.H., De Medieval Debate between Wine and Water, „PMLA” 1913, 28, nr 3, s. $315-367$.

Hezjod, Narodziny bogów (Theogonia), [w:] tegoż, Narodziny bogów (Theogonia). Prace $i$ dni. Tarcza, przełożył, wstępem i przypisami opatrzył J. Łanowski, Warszawa 1999 , s. 31-58.

Horacy, Wybór poezji, oprac. J. Krókowski, Wrocław 2007.

Horatius Q.F., Opera, editio minor tertia, iterum recognovit F. Vollmer, Lipsiae 1927.

Janicki K., Carmina. Dzieła wszystkie, wydał i wstępem (I) poprzedził J. Krókowski, przełożył E. Jędrkiewicz, wstęp (II), komentarz, similia, appendices, słownik imion własnych i indeks oprac. J. Mosdorf, Wrocław 1966.

Katullus, Poezje, przełożyła A. Świderkówna, opracował J. Krókowski, Wrocław 1956.

Klibansky R., Panowsky E., Saxl F., Saturn i melancholia. Studia z historii filozofii, przyrody, medycyny, religii oraz sztuki, przeł. A. Kryczyńska, Kraków 2009.

Knox P.E., Wine, Water, and Callimachean Polemics, „Harvard Studies in Classical Philology" 1985, 89, s. 107-119. 
Kochanowski J., Carmina Latina. Poezja łacińska. Pars prior Imago phototypica transcriptio. Część I. Fototypia-transkrypcja, edidit, praefstione et apparatu critico instruxit / wyd. i wstępem poprzedziła Z. Głombiowska, Gdańsk 2008.

Kochanowski J., Dzieła polskie, wyd. 2, zupełne, wstępem i przypisami opatrzył J. Krzyżanowski, t. 1-3, Warszawa 1953.

Kochanowski J., Fraszki, oprac. J. Pelc, Wrocław 2004.

Kochanowski J., Z łacińska śpiewa Stowian Muza. Elegie foricenia, liryki w przekładzie Leopolda Staffa, wstępem poprzedził Z. Kubiak, Warszawa 1982.

Kostkiewiczowa T., Krytyka literacka $w$ Polsce $w$ epoce oświecenia, [w:] E. Sarnowska-Temeriusz, T. Kostkiewiczowa, Krytyka literacka $w$ Polsce $w$ XVI $i$ XVII wieku oraz $w$ epoce oświecenia, Wrocław 1990, s. 151-341.

Kotarska J., „Kastalskie zdroje Muz”. Z dziejów topiki Apollińskiej, [w:] tejże, Theatrum mundi. Ze studiów na poezja staropolska, Gdańsk 1998, s. 179--196.

Krókowki J., Wstęp, [w:] Horacy, Wybór poezji, oprac. J. Krókowski, Wrocław 2007.

Lenart M., Spór duszy z ciałem i inne wierszowane spory $w$ literaturze staropolskiej na tle tradycji średniowiecznej, Opole 2002.

Lewy H., Sobria ebrietas. Untersuchunden zur Gesachiche der antiken Mystik, Giessen 1929 .

Liryka starożytnej Grecji, oprac. J. Danielewicz, wyd. 3, Wrocław 1987.

Maleszyński D.C., Pszczoła - „archipoeta” (teoria mimesis w dawnej metaforze), [w:] Mimesis $w$ literaturze, kulturze $i$ sztuce, red. Z. Mitosek, Warszawa 1992, s. 273-306.

Maleszyński D.C., Wody u Janicjusza, „Polonistyka” 2012, 76, nr 2 (494), s. 6-9.

Michałowska T., Kochanowskiego „poeta parennis” ( $w$ kregu renesansowych refleksji o poezji), [w:] Jan Kochanowski i epoka renesansu. W 450 rocznicę urodzin poety 1530-1580, red. T. Michałowska, Warszawa 1984 s. 59-82.

Michałowska T., Poetyka i poezja. Studia i szkice staropolskie, Warszawa 1982.

Mojsik T., Antropologia metapoetyki. Muzy w kulturze greckiej od Homera do końca $V w . p . n . e$, Warszawa 2011.

Murray P., Poetic inspiration in Early Greece, „The Journal of Hellenic Studies” 1981, 101, s. 87-100.

Najstarsza poezja polsko-łacińska (do połowy XVI wieku), oprac. M. Plezia, Wrocław 2005.

Nannini S., Simboli e metafore nella poesia simposiale greca, Roma 1988.

Otwinowska B., Iudicium, [hasło w:] Słownik literatury staropolskiej, red. T. Michałowska, przy współudziale B. Otwinowskiej, E. Sarnowskiej-Temeriusz, wyd. 3, Wrocław 2002, s. 354-356.

Pazura S., De gustibus. Rozważania nad dziejami pojęcia smaku estetycznego, Warszawa 1981.

Pelc J., Słowo i obraz. Na pograniczu literatury i sztuk plastycznych, Kraków 2002.

Petrycy z Pilzna S., Przydatki do Etyki Arystotelesowej, [w:] tegoż, Pisma wybrane, oprac. W. Wąsik, wstępem poprzedził K. Grzybowski, t. 1, Warszawa 1956.

Pindar, Ody zwycięskie, olimpijskie, pytyjskie, nemejskie, istmijskie, przekł., wstęp komentarz M. Brożek, Kraków 1987. 
Pizzocaro M., Alcmane e la gastronomia poetica, „AION” 1990, 12, s. 285-308.

Platon, Ion, [w:] tegoż, Dialogi, przekład oraz wstęp i objaśnienia W. Witwicki, t. 1, Kęty 1999, s. 13-39.

Polski Słownik Biograficzny, t. 12: Kapostas Andrzej - Klobassa Zręcki Karol, red. E. Rostworowski, Wrocław-Warszawa-Kraków 1966-1967.

Pudłowski M., Fraszek ksiega pierwsza, [w:] tegoż, Pisma, wyd. T. Wierzbowski, Warszawa 1898, s. 27-73.

Sarnowska-Temeriusz E., Droga na Parnas. Problemy staropolskiej wiedzy o poezji, Wrocław 1974.

Sarnowska-Temeriusz E., Renesansowe pojęcie poezji w Polsce, [w:] Problemy literatury staropolskiej. Seria druga, red. J. Pelc, Wrocław 1973, s. 459-492.

Sarnowska-Temeriusz E., Przeszłość poetyki. Od Platona do Giambattisty Vica, Warszawa 1995.

Stownik polszczyzny XVI wieku, red. S. Bąk, S. Hrabec, W. Kuraszkiewicz i in., t. 4, Wrocław 1969.

Somnium prodigiosum de Vino et Aqua mutuo inter se pro dignitas Apice litigantibus. Sen dziwny, w którym wino $i$ woda o godnościach swych rozprawuja przez I. L. S. I. K. M. napisany, Kraków, Franciszek Cezary 1647.

[Tyszka A.], Poswarek wina z woda, b. r. i m. w. [ok. 1620-1650].

Wesoły M., Ion piewca wina i mądrości, [w:] Litteris vivere. Księga pamiątkowa ofiarowana profesorowi Andrzejowi Wójcickowi, red. I. Lewandowski, K. Liman, Poznań 1996, s. 43-55.

Wojtkowska-Maksymik M., „Gentiluomo cortegiano” $i$ „dworzanin polski”. Dyskusja o doskonałości człowieka $w$ „Il Libro del cortegiano Baldassarra Castiglionego $i$ „Dworzaninie polskim” Łukasza Górnickiego, Warszawa 2007.

Wójcik A., Problematyka literacka w twórczości Horacego, Poznań 1978.

Vossius G.J., De artis poeticae ac constitutione liber, Amstelodami, Ludovicum Elzevirium 1647. 